\title{
An Investigation on Self-Handicapping Levels of Sport Management Students
}

\author{
Ahmet Yalçınkaya ${ }^{1}$, Ziya Bahadır ${ }^{2} \&$ Çağrı Hamdi Erdoğan ${ }^{3}$ \\ ${ }^{1}$ College of Physical Education and Sports, Kırşehir Ahi Evran University, Turkey \\ ${ }^{2}$ Faculty of Sports Sciences, Erciyes University, Turkey \\ ${ }^{3}$ Ministry of Education, Şehit Ahmet Cihan Kilci Middle School, Turkey \\ Correspondence: Çağrı Hamdi Erdoğan, Şehit Ahmet Cihan Kilci Middle School, Selçuklu Mahallesi Kayadibi \\ Sokak No: 5038050 Melikgazi KAYSERİ, Turkey. E-mail: erdoganhamdi@hotmail.com
}

Received: February 8, 2021 Accepted: March 9, 2021 Online Published: March 11, 2021

doi:10.5539/jel.v10n2p152 URL: https://doi.org/10.5539/jel.v10n2p152

\begin{abstract}
This study aims to determine the self-handicapping levels of sports management department students. Furthermore, the study endeavors analyzing the sports management students' self-handicapping level by gender, grade, grade point average, and exercise status. The study group analyzed with the survey method comprise 158 students enrolled in the Faculty of Sports Science for Sport Management Department at Erciyes University, Kayseri/Turkey during the 2018-2019 academic year. The study utilizes "Self-Handicapping Scale" developed by Jones and Rhodewalt (1982) and adapted to Turkish by Akın, Abacı and Akın (2010) as the data collection tool. The SPSS program was used for data analysis. The results indicate that the sports management students' self-handicapping level in the study group was "moderate". Moreover, the self-handicapping levels of the sports management students in the study group did not differ significantly by gender, grade, age and exercise status ( $\mathrm{p}>$ $0.05)$. However, it was discovered that self-handicapping levels significantly differ by grade point average ( $\mathrm{p}<$ $0.05)$.
\end{abstract}

Keywords: self-handicapping, sport management, students

\section{Introduction}

The concept of self-handicapping is defined as choosing a performance or activity environment that enables internalizing success and externalizing failure. Acknowledged impediments, that allow an individual to attribute the roots of failure to external factors with a reduced probability of success, serve the purpose of rationalizing failure (Jones \& Berglas, 1978).

Self-handicapping is rooted in the uncertainty about the future performance of an individual and artificial obstacle to externalize the cause of possible negativities (Leary \& Shepperd, 1986). Self-handicapping behavior emerges in conditions with no logical and reasonable explanation forfailing to achieve the expectations and realize goals (Coşar, 2012).

Individuals usually have a high motivation to improve their abilities through learning from their experiences and failures (Park, Bauer, \& Arbuckle, 2009). However, self-handicapping people find particular excuses to reduce their likelihood of accomplishing an assignment as this provides them with a valid ground for failure. Having excuses before performing an activity, an individual reduces the ability traits in failure and increases them in success (Kelley, 1971). Moreover, a self-handicapping individual aims to provide valid/justifiable explanations for possible failures (Arkin \& Baumgardner, 1985).

Thus, self-handicapping ensures that others' attention is focused on the self-handicapping strategy in case of failure rather than one's skill and ability level as the amount of negative feedback to the person is reduced. It also helps to reflect one's skill and ability level as very high in success because there is a success despite handicapping (Rhodewalt \& Vohs, 2005). Therefore, the individual benefits and achieves advantages regardless of the outcome. The condition of making personal gains by internalizing successes and finding excuses to externalize failures lies in the spirit of this behavior. However, it has been suggested that chronic and extreme forms of rationalization and behavioral self-handicapping can damage the person (Feick \& Rhodewalt, 1997). 
Each individual categorically wants to have a positive self-image and be perceived positively by others (Ben-Zur, 2005). Individuals don't want to be perceived as incompetent by others in case of failure. Therefore, they tend to show and maintain a successful performance in cases with the possibility of a performance assessment. The individual must first be able to manage social inferences related to their talent in self-oriented tasks. Self-handicapping strategies help individuals rationalize their failure. The self-sabotage is an image management strategy used to excuse or externalize failure in this sense (Abac1 \& Akın, 2011).

Contemporary scholarship revealed positive correlations between self-handicapping and depression, anxiety, low self-esteem (Saddler \& Sacks, 1993; Lay \& Silverman, 1996; Martin, Flett, Hewitt, Krames, \& Szanto, 1996) and low academic achievement (Garcia, 1995; Midgley \& Urdan, 1995; Midgley, Arunkumar, \& Urdan, 1996; Urdan, Midgley, \& Anderman, 1998).

Self-handicapping in students develop as an intuitive strategy that some use to neglect other people's perceptions of their incompetence. Handicapping behaviors can be exemplified as behavioral patterns such as insufficient effort, finding excuses, excessive socialization with friends to impede work, delaying academic responsibilities and duties to hinder success (Urdan \& Midgley, 2001). A relevant study found a negative correlation between the need for success and self-handicapping (Elliot \& Church, 2003). Another study discovered a negative correlation between internal motivation and self-handicapping (Deppe \& Harackiewicz, 1996). Previous studies have shown that such circumstances increase the likelihood of self-handicapping behavior (Hirt, McCrea, \& Kimble, 2000).

This study aims to determine the self-handicapping levels of students at the sports management department. It was also aimed to examine the sports management department students' self-handicapping levels based on their age, gender, grade, grade point average, and exercise frequency. It is thought that determining the students' self-handicapping levels at the sports management department will contribute to the literature.

\section{Method}

\subsection{Research Model}

This study applies a general survey model that examines the self-handicapping levels of sports management students. Survey model research is conducted with the information gathered from a large mass through multiple-choice answers determined by the scholars (Fraenkel \& Wallen, 2006).

\subsection{Study Group}

The study group comprises 158 students enrolled in the Faculty of Sports Science for Sport Management Department in Erciyes University, Kayseri/Turkey during 2018-2019 academic year. 73 (46.2\%) of the study group students are female, and $85(53.8 \%)$ are male.

\subsection{Data Collection Tools}

The Personal Information Form and the Self-Handicapping Scale are applied to determine the sports management department students' demographic characteristics and their self-handicapping levels.

Developed by Jones and Rhodewalt (1982), "The Self-Handicapping Scale" is one-dimensional, 6 Likert-type, and consists of 25 items. The 6-point Likert structure of the scale includes ratings by the expressions "1-do not agree at all", "6-completely agree". "Self-Handicapping Scale" has been developed to measure individuals" perceptions of self-handicapping, such as emotional problems, procrastination, and lack of effort. Also, it is a measurement tool based on the individual's statement. The original form of the scale was adapted into Turkish by Akın, Abacı and Akın (2010). After the 3rd, 5th, 6th, 10th, 13th, 20th, 22nd and 23rd items in the scale are reverse coded, the scores of all the items are added, and the self-handicapping score is calculated. Coded items are translated, and high scores show an increased tendency to verbal and behavioral self-handicapping, while low scores show a low verbal and behavioral self-handicapping tendency. Akın (2015) found the Cronbach alpha internal reliability coefficient of the Turkish adaptation of the scale to be .90 , and the test-retest reliability coefficient was calculated as .94 .

\subsection{Data Analysis}

The statistical analysis was performed through the SPSS program. The arithmetic mean $(\overline{\mathrm{x}})$ and standard deviation (sd) values were calculated to examine the self-handicapping levels of the sports management department students in the study group. Besides, the Kolmogorov-Smirnov test is performed to investigate whether the levels of self-handicapping of the sports management department students in the study group show normal distribution. The tests indicate that the distribution is not normal $(p=.000)$. Since the sports management students' self-handicapping levels in the study group do not show a normal distribution, the Mann-Whitney U 
test is used in paired comparisons, and Kruskal Wallis H Test techniques are used in multiple comparisons. The $\mathrm{p}<0.05$ value was defined as the confidence threshold to determine significance.

\section{Findings}

Table 1. Distribution of sports management students in the study group by demographic features

\begin{tabular}{llllll}
\hline Gender & $\mathrm{n}$ & $\%$ & Grade Point Average & $\mathrm{n}$ & $\%$ \\
Male & 85 & 53.8 & Between 1.50-1.99 & 13 & 8.2 \\
Female & 73 & 46.2 & Between 2.00-2.49 & 25 & 15.8 \\
& & & Between 2.50-2.99 & 61 & 38.6 \\
Age & $\mathrm{n}$ & $\%$ & Between 3.00-3.49 & 59 & 37.3 \\
Between the ages of 18-20 & 54 & 34.2 & & & \\
Between the ages of 21-23 & 72 & 45.6 & Grade & n & $\%$ \\
24 Years and above & 32 & 20.3 & 1st grade & 54 & 34.2 \\
& & & 2nd grade & 51 & 32.3 \\
Doing Regular Exercise & $\mathrm{n}$ & $\%$ & 3rd grade & 34 & 21.5 \\
Yes & 89 & 56.3 & 4th grade & & \\
No & 69 & 43.7 & Total n: 158 & & \\
& & &
\end{tabular}

The demographic characteristics of the sports management department students in the study group are presented in Table 1 .

Table 2. Self-handicapping scale general average of the sports management students in the study group

\begin{tabular}{lllll}
\hline Scale & $\mathrm{n}$ & Min-Max & $\overline{\mathrm{X}}$ & $\mathrm{sd}$ \\
\hline The Self-Handicapping Scale & 158 & $1-6$ & 3.39 & 0.511 \\
\hline
\end{tabular}

The sports management students' Self-handicapping scale score average is presented in Table 2. According to the analysis results, it has been determined that the sports management students obtain $\overline{\mathrm{X}}=3.39$ points from the overall self-handicapping scale. Based on this result, the sports management department students' self-handicapping level in the study group can be interpreted as "moderate".

Table 3. Comparison of the sports management department students' self-handicapping levels in the study group according to their gender and exercise status

\begin{tabular}{lllllll}
\hline & & $\mathrm{n}$ & Mean Rank & Sum of Ranks & $\mathrm{U}$ & $\mathrm{p}$ \\
\hline GENDER & Male & 85 & 78.75 & 6693.50 & 3038.5 & .823 \\
& Female & 73 & 80.38 & 5867.50 & & \\
DOING REGULAR EXERCISE & Yes & 89 & 76.50 & 6808.50 & 2803.5 & .349 \\
& No & 69 & 83.37 & 5752.50 & & \\
\hline
\end{tabular}

The comparison of the sports management department students' self-handicapping levels in the study group according to their gender and exercise status is presented in Table 3. The analysis results indicate that sports management students' self-handicapping level in the study group does not differ significantly by gender and exercise status.

Table 4. Comparison of the sports management students' self-handicapping levels in the study group by age, grade and grade point averages

\begin{tabular}{llllllll}
\hline & & $\mathrm{n}$ & Mean Rank & $\mathrm{df}$ & $\mathrm{x}^{2}$ & $\mathrm{p}$ & Significant Difference \\
\hline AGE & Between the ages of 18-20 & 54 & 72.64 & 2 & 3.605 & .165 & \\
& Between the ages of 21-23 & 72 & 87.03 & & & & \\
24 Years and above & 32 & 74.14 & & & \\
& 1st Grade & 19 & 68.55 & 3 & 4.986 & .173 & \\
& 2nd Grade & 54 & 76.70 & & & & \\
& 3rd Grade & 51 & 90.71 & & & \\
& 4th Grade & 34 & 73.25 & & & \\
\end{tabular}




\begin{tabular}{|c|c|c|c|c|c|c|c|}
\hline GRADE & Between 1.50-1.99 (a) & 13 & 80.46 & 3 & 10.083 & $.018^{*}$ & $a-b$ \\
\hline POINT & Between $2.00-2.49$ (b) & 25 & 104.66 & & & & $\mathrm{c}-\mathrm{b}$ \\
\hline AVERAGE & Between $2.50-2.99$ (c) & 61 & 77.99 & & & & $d-b$ \\
\hline & Between $3.00-3.49$ (d) & 59 & 70.19 & & & & \\
\hline
\end{tabular}

Note. ${ }^{*} \mathrm{p}<0.05$.

The comparison of sports management students' self-handicapping levels in the study group by age, grade and grade point average is demonstrated in Table 4 . The analysis results did not indicate a significant difference in sports management students' self-handicapping levels by age and grade, but the grade point average parameter exhibits a significant difference. The students with a grade point average between $2.00-2.49$ show a significant difference in self-handicapping levels.

\section{Discussion}

Kamuk and Şensoy (2019) revealed that the referees' self-handicapping levels working in the wave surfing branch were low. Büyükgöze and Gün (2015) found that research assistants' self-handicapping tendencies were also low. The results showed that the self-handicapping level of the sports management students was "moderate". The research conducted contradicts the results of these studies in terms of the level of self-handicapping.

Several studies, Anlı (2011), Anlı, Akın, Şar and Eker (2015), Kalyon, Dadandı and Yazıcı (2016), Kamuk (2019), reached results implying that the participants' self-handicapping levels differed significantly by gender. Berglas and Jones (1978), Midgley et al. (1996), Urdan et al. (1998) discovered that males self-handicap more than females. On the contrary, Sheppard and Arkin (1989) and Strube and Roemmele (1985) determined that the self-handicapping levels of females are higher than that of males. According to Üzbe (2013), the self-handicapping strategies used by males and females differ. Zuckerman and Tsai (2005) and Büyükgöze and Gün's (2015) attempts proved against significant differences in participants' self-handicapping levels by gender. Moreover, Kamuk, Evli and Tecimer (2018) revealed no significant difference regarding male and female football referees' self-handicapping levels. This study detected no significant difference in sports management students' self-handicapping levels by gender. The self-handicapping level results of some of the mentioned studies show similarities with this research in terms of gender, but it seems that some of them are contradictory.

Coşar (2012) stated that the employee age and self-handicapping has a negative correlation. Topal, Yalnızoğlu Çaka and Çınar (2018) found that younger nursing students had higher levels of self-handicapping. Kamuk et al. (2018) determined that football referees' self-handicapping levels exhibit significant difference by age. Zafer (2016) determined that participants' self-handicapping levels did not show significant differences by age in firefighters aged between 20 and 40. This study detected no significant difference in sports management students' self-handicapping levels by age. The self-handicapping results of some of the mentioned studies are in parallel with this study in terms of age, but some of them were found to be reverse.

Fleming (2007) found that grade and self-handicapping have a positive correlation. Çingöz (2015) revealed that university students' self-handicapping levels differ significantly by grade. Üzbe's (2013) attempt on self-handicapping scores by grade detected no significant differences. Taş (2017) illustrated no significant difference in university students' self-handicapping levels by their grade. This study detected no significant difference in sports management students' self-handicapping levels by grade. Although the self-handicapping results of some of the mentioned studies were compatible with this study in terms of grade, some of them were found to be incompatible.

Çelik and Atilla (2019) concluded that the volunteered students' self-handicapping tendencies showed a significant difference in terms of perceived academic competence. The results specified that sports management students' self-handicapping levels have a significant difference by the grade point average. The mentioned research is similar to the results of the self-handicapping level in terms of the grade point average of the research.

Çingöz (2015) determined that university students' self-handicapping levels differ significantly according to their regular exercise status. This study detected no significant difference in sports management students' self-handicapping levels for this variable and the results are contrary to the mentioned study.

\section{Conclusion}

Sports management students' self-handicapping levels were analyzed through this study. Furthermore, the sports management students' self-handicapping levels were analyzed by gender, grade, grade point average, and regular exercise status. The results indicate that the sports management students' self-handicapping level in the study group was "moderate". Moreover, while the self-handicapping levels of the sports management students in the 
study group did not differ significantly by gender, grade, age and exercise status and it was discovered that self-handicapping levels point to a significant difference by grade point average.

\section{Recommendations}

The results propound the idea that sports management students' moderate self-handicapping level can be considered a positive aspect. It may be suggested for these students to seek expert support to improve their ability to cope with failure. Contemporary scholarship can improve with further research on the topic with more extensive participation. Similar qualitative research on self-handicapping is necessary.

\section{References}

Abac1, R., \& Akın, A. (2011). Self-Handicapping. Ankara, Turkey: Pegem Academy Publications.

Akın, A. (2015). Current Measurement Tools Used in Psychology (2nd ed.). İstanbul, Turkey: Nobel Academy Publications.

Akın, A., Abac1, R., \& Akın, Ü. (2010). Self-handicapping Scale: A study of Validity and Reliability. 16th National Psychology Congress, April 14-17, Mersin, Turkey.

Anl, G. (2011). Examining the relationship between self-handicapping and psychological well-being in terms of different variables. Master's thesis, University of Sakarya, Sakarya, Turkey. Retrieved from https://tez.yok.gov.tr

Anlı, G., Akın, A., Şar, A. H., \& Eker, H. (2015). Examining the relationship between self-handicapping and psychological well-being in terms of different variables. Electronic Journal of Social Sciences, 14(54), $160-172$.

Arkin, R. M., \& Baumgardner, A. H. (1985). Self-Handicapping. In J. H. Harvey \& G. Weary (Eds.), Attribution Basic Issues and Applications. New York: Academic Press.

Ben-Zur, H. (2005). Optimism, social comparisons, and coping with vision loss in Israel. Journal of Visual Impairment \& Blindness, 99(3), 151-164. https://doi.org/10.1177/0145482X0509900304

Berglas, S., \& Jones, E. E. (1978). Drug chose as self handicapping strategy in response to noncontingent success. Journal of Personality and Social Psychology, 95(4), 405-417. https://doi.org/10.1037/0022-3514.36.4.405

Büyükgöze, H., \& Gün, F. (2015). An investigation of research assistants' self-handicapping tendencies. Hitit University Journal of Social Sciences Institute, 8(2), 689-704.

Çelik, Y., \& Atilla, G. (2019). Self-handicapping, fear of negative evaluation and selfesteem of university students. Journal of Kahramanmaraş Sütçü İmam University Faculty of Economics and Administrative Sciences, 9(2), 177-198.

Çingöz, B. (2015). University student's investigate the relationship between different variables and self sabotage levels of sport. Master's thesis, Ağrı İbrahim Çeçen University, Ağrı, Turkey. Retrieved from https://tez.yok.gov.tr

Coşar, S. (2012). Investigation of the relationship between employee burnout levels and levels of self-handicapping. Master's thesis, University of Maltepe, İstanbul, Turkey. Retrieved from https://tez.yok.gov.tr

Deppe, R. K., \& Harackiewicz, J. M. (1996). Self-handicapping and intrinsic motivation: Buffering intrinsic motivation from the threat of failure. Journal of Personality and Social Psychology, 70(4), 868. https://doi.org/10.1037/0022-3514.70.4.868

Elliot, A. J., \& Church, M. A. (2003). A motivational analysis of defensive pessimism and self - handicapping. Journal of Personality, 71(3), 369-396. https://doi.org/10.1111/1467-6494.7103005

Feick, D. L., \& Rhodewalt, F. (1997). The double-edged sword of selfhandicapping: Discounting, augmentation, and the protection and enhancement of self-esteem. Motivation and Emotion, 21(2), 147-163. https://doi.org/10.1023/A:1024434600296

Fleming, A (2007). Perception of ability, trait affectivity, and self-handicapping behavior in adolescents. Doctoral dissertation. Retrived from ProQuest dissertations and thesis database (NR3244139).

Garcia, T. (1995). The role of motivational strategies in self-regulated learning. New Directions in Teaching and Learning, 63, 29-42. https://doi.org/10.1002/tl.37219956306 
Hirt, E. R., McCrea, S. M., \& Kimble, C. E. (2000). Public self-focus and sex differences in behavioral self-handicapping: Does increasing self-threat still make it "just a man's game?" Personality and Social Psychology Bulletin, 26, 1131-1141. https://doi.org/10.1177/01461672002611009

Jones, E. E., \& Berglas, S. (1978). Control of attributions about the self through self-handicapping strategies: The appeal of alcohol and the role of underachievement. Personality and Social Psychology Bulletin, 4, 200-206. https://doi.org/10.1177/014616727800400205

Jones, E. E., \& Rhodewalt, F. (1982). The Self-Handicapping Scale. Available from Frederick Rhodewalt, Department of Psychology, University of Utah, Salt Lake City, UT 84112. https://doi.org/10.1037/t09528-000

Kalyon, A., Dadand1, İ., \& Yazıcı, H. (2016). The relationships between self-handicapping tendency and narcissistic personality traits, anxiety sensitivity, social support, academic achievement. The Joyrnal of Psychiatry and Neurological Sciences, 29(3), 237-246. https://doi.org/10.5350/DAJPN2016290305

Kamuk, Y. U. (2019). Self-handicapping and self-esteem levels of badminton umpires. Journal of Global Sport and Education Research, 2(2), 19-33.

Kamuk, Y. U., Evli, F., \& Tecimer, H. (2018). Self-handicapping levels of football referees. Hitit University Journal of Social Sciences Institute, 11(3), 2257-2267. https://doi.org/10.17218/hititsosbil.461486

Kamuk, Y. U., \& Şensoy, E. (2019). Self-handicappıng levels of wavesurf judges. Turkish Studies Social Sciences, 14(3), 683-695. https://doi.org/10.29228/TurkishStudies.22610

Kelley, H. H. (1971). Attribution in Social Interaction. In E. E. Jones, D. E. Kanouse, H. H. Kelley, R. E. Nisbett, S. Valins \& B. Weiner (Eds.), Attribution: Perceiving the Causes of Behavior. Morristown, New Jersey: General Learning Press.

Lay, C., \& Silverman, S. (1996). Trait procrastination, anxiety and dilatory behavior. Personality and Individual Differences, 21, 61-67. https://doi.org/10.1016/0191-8869(96)00038-4

Leary, M. R., \& Shepperd, J. A. (1986). Behavioral self-handicaps versus self reported selfhandicaps: A conceptual note. Journal of Personality and Social Psychology, 51, 1265-1268. https://doi.org/10.1037/0022-3514.51.6.1265

Martin, T., Flett, G., Hewitt, P., Krames, L., \& Szanto, G. (1996). Personality correlates of depression and health symptoms: A test of a self-regulation model. Journal of Research in Personality, 31, 264-277. https://doi.org/10.1006/jrpe.1996.0017

Midgley, C., Arunkumar, R., \& Urdan, T. C. (1996). "If i don’t do well tomorrow, there's a reason": predictors of adolescents' use of academic self-handicapping strategies. Journal of Educational Psychology, 88(3), 423-434. https://doi.org/10.1037/0022-0663.88.3.423

Midgley, C., \& Urdan, T. (1995). Predictors of middle school students' use of self-handicapping strategies. Journal of Early Adolescence, 15, 389-411. https://doi.org/10.1177/0272431695015004001

Park, S. W., Bauer, J. J., \& Arbuckle, N. B. (2009). Growth motivation attenuates the self-serving attribution. Journal of Research in Personality, 43, 914917. https://doi.org/10.1016/j.jrp.2009.04.013

Rhodewalt, F., \& Vohs, K. (2005). Defensive Strategies, Motivation and The Self: A Self Regulatory Process View. In A. J. Elliot \& C. S. Dweck (Eds.), Handbook of Competence and Motivation. New York: Guilford Press

Saddler, C. D., \& Sacks, L. (1993). Multidimensional perfectionism and academic procrastination: Relationship with depression in university students. Psychological Reports, 73, 863-871. https://doi.org/10.2466/pr0.1993.73.3.863

Shepperd, J. A., \& Arkin, R. M. (1989). Determinants of self-handicapping: Task importance and the effects of pre-existing handicaps on self-genareted handicaps. Personality and Social Psychology Bulletin, 15, 101-112. https://doi.org/10.1177/0146167289151010

Strube, M. J., \& Roemmele, L. A. (1985). Self-enhancement, self-assessment and self-evaluative task choice. Journal of Personality and Social Psychology, 49, 981-993. https://doi.org/10.1037/0022-3514.49.4.981

Taş, R. (2017). Research of the effect of university students' interpersonal competency levels in romantic relationships on self-handicapping tendencies. Master's thesis, University of Erciyes, Kayseri, Turkey. Retrieved from https://tez.yok.gov.tr 
Topal, S., Yalnızoğlu, Ç. S., \& Çınar, N. (2018). Determination of the relationship between self-handicapping and burneout of nursing students. Çukurova University Journal of Education Faculty, 47(1), 337-356. https://doi.org/10.14812/cuefd.380804

Urdan, T., \& Midgley, C. (2001). Academic self-handicapping: What we know, what more there is to learn. Educational Psychology Review, 13(2), 115-138. https://doi.org/10.1023/A:1009061303214

Urdan, T., Midgley, C., \& Anderman, E. (1998). The role of classroom goal stracture in student' use of self-handicapping strategies. American Educational Research Journal, 35, 101-122. https://doi.org/10.3102/00028312035001101

Üzbe, N. (2013). The role of achievement goal orientation, self esteem and academic achievement in prediction of self handicapping. Master's thesis, University of Gazi, Ankara, Turkey. Retrieved from https://tez.yok.gov.tr

Zafer, M. (2016). The study of resilience and self-sabotage levels in fire-fighters: A case study of Istanbul Fire Department. Master's thesis, University of Nişantaşı, İstanbul, Turkey. Retrieved from https://tez.yok.gov.tr

Zuckerman, M., \& Tsai, F. F. (2005). Cost of self-handicapping. Journal of Personality, 73(2), 411-442. https://doi.org/10.1111/j.1467-6494.2005.00314.x

\section{Copyrights}

Copyright for this article is retained by the author, with first publication rights granted to the journal.

This is an open-access article distributed under the terms and conditions of the Creative Commons Attribution license (http://creativecommons.org/licenses/by/4.0/). 